\title{
Service Learning Through Mission and Ministry
}

\author{
Clarissa Lopez* \& Kaun Chen Tsai** \\ *University of the Incarnate Word, San Antonio, Texas 78209, USA \\ E-mail: clherrer@student.uiwtx.edu \\ **Correspondence: University of the Incarnate Word, San Antonio, Texas 78209, USA \\ E-mail:ktsai@student.uiwtx.edu
}

Received: May 2, 2012 Accepted: May 12, 2012 Published: March 16, 2012

doi:10.5296/ije.v4i2.1734 URL: http://dx.doi.org/10.5296/ije.v4i2.1734

\begin{abstract}
The purpose of this study was to determine if student's perceptions of service learning projects lead to an understanding the mission of the University of the Incarnate Word. It is through the service learning opportunity that a window opens to determine if students gain a prospective of service learning and the meaning of the mission of the institution. The research findings revealed moderate positive relationships among students' perceptions of learning service projects and the students' understanding of the mission of the institution. The implications and limitations of this study are discussed.
\end{abstract}

Keywords: service learning, experimental learning, reflective observation, university mission 


\section{Introduction}

In an attempt to promote the mission through service learning, the University of the Incarnate Word (UIW) in San Antonio, Texas offers opportunities for students to become engaged in community projects. UIW is a Catholic university and the catholic mission of service, education, moral values, world concerns, and ecumenism could be integrated into student experience through the vehicle of service learning.

Service learning has long been a needed element within the walls of academia. Insights to experiential learning, critical reflection, and how small classes affect the student transformation are a much needed area for instructors of higher education. Service learning projects provide challenges, discomforts, confidence, and competency to the students who participate in these community service opportunities while adding to the understanding of the university and its mission of service (Deely, 2010).

The students of the College Environment course at the University of the Incarnate Word had an opportunity to conduct a service learning project within the week of Spring Break 2012 through the Mission and Ministry campaign. The objective of the project was to paint the homes of the elderly population who have no means to pay for the service. Through the opportunity of service learning, a window opened to explore if students gain a prospective of service learning and the meaning of the mission of the University of the Incarnate Word.

\section{Purpose of the Study}

England and Marcinkowski (2007) posited that service learning is designed to provide an educational opportunity for students to become involved in the community. However, there are only limited amounts of studies (e.g., Lee, 1999; Roberts, 2008) available on the effects between service learning studies and institution mission. A gap in the literature shows how the effects of service learning can be critically analyzed in creating positive awareness of the institution mission (Deely, 2010). As a result, the purpose of this study is to determine if students' perceptions of service learning projects lead to an understanding the mission of the University of the Incarnate Word.

\section{Research Question}

What is the relationship between the students' perceptions of learning service projects and the students' understanding of the mission of the institution? The researchers hypothesized that there is no relationship between students' perceptions of learning service projects and the students' understanding of the University of the Incarnate Word mission.

\section{Significance}

If a gap in service learning projects and understanding of the UIW mission can be established, the study could assist faculty in addressing possible curriculum change. This project fits into the University's mission of Solidarity in that we are our brothers and sisters keepers. The measurable objectives to be accomplished by this project are improvements to how the students and faculty of institution may be of service to the surrounding communities. 


\section{Literature Review}

\section{The Promising Ground of Service Learning}

Service learning has multiple meanings depending on the literature being presented. A review of the literature describes service learning as a process, pedagogy, philosophy, and experience (Novak, 2010; Ottenritter, 2004; Redman \& Clark, 2002). D'Agostino (2010) defined service learning as a combination of service through community activity and learning in application of learned concepts to knowledge. The focus of service learning is grounded in the assumption that learning and teaching within a social context facilitates socially responsive knowledge (Conway, Amel, \& Gerwien, 2009). Essentially, service learning can be seen as knowledge that is evidence-based supported by theory with a process direction (Ottenritter, 2004). Based on a meta-analysis of service learning, Conway et al (2009) identified four categories of outcomes related to social learning, including academic, personal, social and citizenship. They found service learning does not always have positive effects on those four outcomes. However, the largest effects of academic outcomes and of beliefs, knowledge, and attitudes toward those being served were found.

Green, Cpmer, Elliott, and Neubrander (2011) found that the positive experience of service learning that is not only transformative for students, but also gives them the chance to work outside their comfort zones. Service learning entails utilizing course work and voluntary service in the form of community work. The experience of service learning exhibits personal autonomy, bonding, and teamwork (Basi, 2011). The benefits of this pedagogical tool are located in implementation of course knowledge allowing students and the community to reap the profits (Yi \& Lambright, 2010).

It is through critical reflection that students are expected to make connections between what has been learned in the classroom versus the community service. Research suggested more in-class reflection time could improve students' skills (e.g., interpersonal, problem-solving, and leadership skills) (Yi \& Lambright, 2010). Several scholars argued the utility of service learning on knowledge construction occurs through reflection on experience and development of new concepts leading to additional new concepts (Conway et al., 2009).

Many students engage in projects that promote giving back to the community. It is believed that the experience the student encounters through service learning will develop the cognitive and affective concepts needed for the student's personal development (Deeley, 2010). Yi and Lambright (2010) posited a number of factors could influence the effectiveness of service learning, including activities which require the instructors guidance, as well as personal reflection time, group work, and understanding the application of past to present.

Roberts (2011) suggested promoting collegial student involvement in community projects to continue prior too high school involvement. Service learning projects give the student the ability to understand the needs of the community and the kinds of contributions students can be part of in assisting the less fortunate. Schuh, Jones, Harper and Associates (2011) also encouraged colleges to get students involved in service learning by matching the interests of the students with the service needed in the community. The authors suggested that 
service learning provides an opportunity for students to offer community services at a decreased cost while providing a much needed service to less fortunate citizens. College campuses who offer service learning opportunities for the students enhance their own commitments to the community and show enrolled students the mission of the school through community involvement.

\section{Potential Learning Opportunities through Experimental Learning}

Knowledge, action, and reflection are three components embedded in experimental learning (Sterling, 2007). Kolb (1984) describes experiential learning as a process that begins with a concrete experience or feeling as the individual comes into contact with a new learning experience. Since each person learns in a different manner and mode, the steps will be individualized to the person. The individual experiences reflective observation and abstract conceptualization. Active experimentation is accompanied by diverging, assimilation, converging and accommodation. Confrontation is the most influential factor in the learning process to the individual. Du Toit and Wilkinson (2010) stated that experimental learning is a form of anticipatory reflection, reflection-in-action, and reflection on reflection, which in turn affect the quality of student learning and learning outcomes.

The literature showed service learning projects as an appropriate assessment of experimental learning in higher education (Chan, 2012). A number of studies had demonstrated the promising features of experimental service learning projects in higher education. Especially, service learning projects not only augment student learning and motivation, but also increase experimental learning opportunities for their professional experience (e.g., Du Toit \& Wilkinson, 2010; Most, 2011; Poon, Chan, \& Zhou, 2011; Soslau \& Yost, 2007; Sterling, 2007). The value of experimental learning in higher education is to strengthen the capacity building in ever more competitive world. Service learning could strengthen the professional development which serves as a means of preparation for students' future careers (Mirrer, 2010). Additionally, the integration of experimental learning and service learning will maximize the students' learning experience and learning output (Baohua, Rongzhen, Jie, \& Qiao, 2010; Butin, 2007; Kronick, 2007; Parker et al., 2009). The rationale behind this is grounded in expansion tacit knowledge of practitioners in the field and in reflecting on their rich experience, thereby reinforcing self-examination and personal growth (Ball, 2008).

\section{Methods}

\section{Research Design}

This study was utilized a cross-sectional survey design. The participants completed the questionnaire at one point in time. The focus was to examine the relationship between students' perceptions of learning service projects and the students' understanding of the mission of the institution. Owing to the nature of this study, the researchers outlined the rationale of the questionnaire and exhibited preliminary analyses that illustrate the usefulness of the notion. The independent variable of this study was students' perceptions of learning service projects. The dependent variable was the students' understanding of the mission of 
the institution. Responses were solicited using 5-item, 5- point Likert-type scale, ranging from "strongly disagree" (1) to "strongly agree" (5) (Creswell, 2007).

\section{Sample and Procedure}

Because of time constraints in conducting this research design, convenience sampling was used for this study. Participants were 70 University of the Incarnate Word students, recruited from a community service learning class during Spring Break week at the Mission and Ministry service learning project. Once permission was granted by the Institution of Review Board, the students of the College Environment course collected the data at the end of each day for five days after the service had been completed. The College Environment course students instructed the participants that the survey was voluntary and that they could choose not to participate in the study. A statement of informed consent for participation in research was also obtained.

\section{Instrument}

The instrument was adapted from Creswell (2007) with five questions (see Appendix A). Participants in this pilot test also provided written comments directly on the survey; thereby researchers could modify or change the survey to reflect those concerns. To determine the validity of the survey instrument, a pilot study was conducted on March 8, 2012 to determine if the questionnaire was reliable. To establish reliability of the instrument, a Cronbach's Alpha was .735 acquired for the instrument used during the study which proved reliability (Cronk, 2008).

\section{Study Results}

Thirty eight surveys were completed by the sample population. Initially of the 70 people who participated in the project, only 38 people met the criteria for the sample. In this study, 14 students were male and 24 students were female. Student's age ranged from 18 to 56 years old. The educational level of students ranged from freshmen to PhD students.

Table 1 shows overall over $50 \%$ of response giving positive result (strongly agree) among five questions. Regarding whether students agree the service project mission statement of the UIW was clear after the project was conducted, 55\% of the students strongly agree the service project mission statement of UIW was clear. The results of student commitment to helping others in the community, over $70 \%$ of the students strongly agree the service learning activity made them feel their commitment to helping others in the community. The next question is whether students believe the project enhanced their personal development as a college student, $50 \%$ of the students strongly agree that today's project enhanced their personal development as a college student, whereas about $2 \%$ of students disagreed with this statement. For the fourth question, whether the service project gives the student the ability to understand the needs of the community, approximately $68 \%$ of the students strongly agree the service project gives the student the ability to understand the needs of the community. Finally the last question asked whether students make the connection between what was learned in the classroom and the community service 
conducted, only $47 \%$ of the students strongly agree the service project made a connection between knowledge learned from the classroom and experience learned from the community service, while about $2 \%$ of the students expressed their strong disagreement of this statement.

Table 1: Responses to Survey Question Regarding Mission of UIW ( $N=38$ )

\begin{tabular}{cccccc}
\hline Response on scale & Mission & Commitment & Development & Understand & Connection \\
\hline Response 5(\%) & 55.3 & 73.7 & 50 & 68.4 & 47.4 \\
Response 4(\%) & 39.5 & 23.7 & 42.1 & 31.6 & 34.2 \\
Response 3(\%) & 2.6 & 2.6 & 5.3 & 0 & 15.8 \\
Response 2(\%) & 2.6 & 0 & 2.6 & 0 & 0 \\
Response 1(\%) & 0 & 0 & 0 & 0 & 2.6 \\
$M$ & 4.47 & 4.71 & 4.39 & 4.68 & 4.23 \\
SD & .69 & .51 & .72 & .47 & .91 \\
\hline
\end{tabular}

The hypothesis suggested that that there is no relationship between students' perceptions of learning service projects and the students' understanding of the University of the Incarnate Word mission. Table 2 describes a spearman correlation which was run to determine the strength of the relationship between the mission and perceptions of the students. A moderate positive correlation was found, rho $(38)=.39, p<.05$, indicating a significant relationship between the between the students' perceptions of learning service projects and the students' understanding of the University of the Incarnate Word mission.

Table 2: Correlation Matrix $(N=38)$

\begin{tabular}{lcccccc}
\hline Variable & 1 & 2 & 3 & 4 & 5 & 6 \\
\hline Mission & -- & & & & & \\
Commitment & $.33^{*}$ & -- & & & & \\
Development & .18 & $.61^{* *}$ & -- & & & \\
Understand & $.51^{* *}$ & $.38^{*}$ & .30 & -- & & \\
Connection & $.33^{*}$ & $.36^{*}$ & $.65^{* *}$ & .30 & -- & \\
Service learning & $.39^{*}$ & $.71^{* *}$ & $.91^{* *}$ & $.55^{* *}$ & $.80^{* *}$ & -- \\
\hline
\end{tabular}

$* p<.05 . * * p<.01$

\section{Discussion}

The merits of service learning not only provide hands-on learning experience, but also develop students' professional skills. Most important, service learning provides enrichment for students' existing knowledge through an action stage where this learning affects their lives and communities (Ottenritter, 2004; Yi \& Lambright, 2010). Consequently, Basi (2011) contended service learning is a gainful endeavor for all parties.

The service learning project through the Mission and Ministry was a small study of 38 student participants from the University of the Incarnate Word. While the population sample was small, the findings were significant to confirm that there is a relationship between students' perceptions of learning service projects and the students' understanding of the 
mission of the institution. This service learning study also demonstrated interesting preliminary findings of how the students related to the project. The students understanding the project in relation to the mission of the university is vital because it is important for those students who remember the reasons for service within the community. On the other hand, the responsibility of faculty is also imperative to facilitate this process. By doing so they could provide the professional assistance needed by the student in terms of research support, planning and guidance in student learning opportunities. Faculty can also serve as a catalyst by providing service-learning events between university students and nonprofit and community agencies (Rosner-Salazar, 2003).

\section{Limitations and Recommendations}

Convenience sampling was used for this study from a small, private university in the United States. Further, the participants were only 38 college and graduate students. Therefore, the generalizability of the study's findings and the representativeness of the sample to the population are questionable. Further research should consider broadening the scope of the sample to include a variety of universities with cross discipline, different sizes, and affiliations. The findings were correlational and susceptible to common method error. A mix method which includes qualitative data would be beneficial in offering insights into the actual classroom experience of students and the reflections of their evaluation.

\section{Acknowledgements}

We appreciate Weida Cotts, M. Sharon Herbers, Ed.D, Samira Lopez, Christine Schmidt, and Lisa Van Slyke for their assistance with data collection.

\section{References}

Ball, M. (2008). Practicums and service learning in LIS education. Journal of Education for Library \& Information Science, 49(1), 70-82.

Baohua, H., Rongzhen, Y., Jie, L., \& Qiao, Z. (2010). Practice and exploration of participatory environmental education in colleges and universities. Chinese Education \& Society, 43(2), 94-102. http://dx.doi.org/10.2753/CED1061-1932430209

Basi, S. (2011). Undergraduate nursing students' perceptions of service-learning through a school-based community project. Nursing Education Perspectives, 32(3), 162-167. http://dx.doi.org/10.5480/1536-5026-32.3.162

Butin, D. W. (2007). Justice-learning: Service-learning as justice-oriented education. Equity $\begin{array}{llll}\text { \& Excellence in } & \text { Education, }\end{array}$ http://dx.doi.org/10.1080/10665680701246492

Chan, C. (2012). Assessment for community service types of experiential learning in the engineering discipline. European Journal of Engineering Education, 37(1), 29-38. http://dx.doi.org/10.1080/03043797.2011.644763 
Conway, J. M., Amel, E. L., \& Gerwien, D. P. (2009). Teaching and learning in the social context: A meta-analysis of service learning's effects on academic, personal, social, and citizenship outcomes. Teaching of Psychology, 36(4), 233-245. http://dx.doi.org/10.1080/00986280903172969

Creswell, J. W. (2007). Educational research: Planning, conducting, and evaluating quantitative and qualitative research. Boston, MA: Pearson Education.

Cronk, B. C. (2008). How to use SPSS: A step by step guide to analysis and interpretation. Glendale, CA: Pyrczak.

D'Agostino, M. (2010). Measuring social capital as an outcome of service learning. Innovative Higher Education, 35(5), 313-328. http://dx.doi.org/10.1007/s10755-010-9149-5

Deeley, S. J. (2010). Service-learning: Thinking outside the box. Active learning in higher education, 11, 43-45. http://dx.doi.org/10.1177/1469787409355870

Du Toit, S. J., \& Wilkinson, A. C. (2010). Research and reflection: Potential impact on the professional development of undergraduate occupational therapy students. Systemic $\begin{array}{llll}\text { Practice } \& \text { Action } & \text { Research, 387-404. }\end{array}$ http://dx.doi.org/10.1007/s11213-010-9165-5

England, Y. A., \& Marchinkowski, T (2007). Environmental service-learning programs in Florida high schools and colleges: Nature, status, and effects as determined by a statewide program census. Summers, 38, 51-60.

Green, S. S., Cpmer, L., Elliott, L., \& Neubrander, J. (2011). Exploring the value of an international service-learning experience in Honduras. Nursing Education Perspectives, 32(5), 302-307. http://dx.doi.org/10.5480/1536-5026-32.5.302

Kolb, D. A. (1984). Experiential learning: Experience as the source of learning and development. Upper Saddle River, NJ: Prentice Hall.

Kronick, R. F. (2007). Service learning and the university student. College Student Journal, 41(2), 296-304.

Lee, D. M. (1999). Reinventing the university: From institutions to communities of higher education. Journal of Adult Development, 6(3), 175-183.

Mirrer, K. (2010). Designing new technologies to expand knowledge and information sharing in internship and experiential learning settings. International Journal of Technology, Knowledge \& Society, 6(4), 121-135.

Most, L. R. (2011). Hands on from a distance: The community-embedded learning model contextualizes online student coursework. Journal of Education for Library \& Information Science, 52(4), 295-304. 
Novak, J. (2010). Learning through service: A course designed to influence positively students' disability-related attitudes. Journal of Education for Teaching, 36(1), 121-123. http://dx.doi.org/10.1080/02607470903462263

Ottenritter, N. W. (2004). Service learning, social justice, and campus health. Journal of American College Health, 52(4), 189-191.

Parker, E., Myers, N., Higgins, H., Oddsson, T., Price, M., \& Gould, T. (2009). More than experiential learning or volunteering: A case study of community service learning within the Australian context. Higher Education Research \& Development, 28(6), 585-596. http://dx.doi.org/10.1080/07294360903161147

Poon, P., Chan, T., \& Zhou, L. (2011). Implementation of service-learning in business education: Issues and challenges. Journal of Teaching in International Business, 22(3), 185-192. http://dx.doi.org/10.1080/08975930.2011.653746

Redman, R. W., \& Clark, L. (2002). Service-learning as a model for integrating social justice in the nursing curriculum. Journal of Nursing Education, 41(10), 446-449.

Roberts, D. C. (2011). Community development. In J. H. Schuh, S. R. Jones, S. R. Harper, \& Associates (Eds.), Student services: A handbook for the profession (pp. 448-467). San Francisco, CA: Jossey-Bass.

Roberts, K. (2008). Service, ethnography, and the "leap of faith": A Spiritan catholic perspective on service learning. Catholic Education: A Journal of Inquiry \& Practice, 12(1), 96-116.

Rosner-Salazar, T. (2003). Multicultural service-learning and community-based research as a model approach to promote social justice. Social Justice, 30(4), 64-76.

Schuh, J. H., Jones, S. R., Harper, S. R., \& Associates (2011). Student services. A handbook for the profession. San Francisco, CA: Jossey-Bass.

Soslau, E. G., \& Yost, D. S. (2007). Urban service-learning: An authentic teaching strategy to deliver a standards-driven curriculum. Journal of Experiential Education, 30(1), 36-53.

Sterling, M. (2007). Service-learning and interior design: A case study. Journal of Experiential Education, 29(3), 331-343.

Yi, L., \& Lambright, K. T. (2010). Looking beyond the undergraduate classroom: Factors influencing service learning's effectiveness at improving graduate students' professional skills. College Teaching, 58(4), 118-126. http://dx.doi.org/10.1080/87567550903583777 


\section{Appendix A}

Service Learning Survey Questionnaire

Using the following 1-5 scale, please indicate, by circling the most correct response for student's perceptions of learning service:

Please circle the survey questions below:

Gender: $\mathrm{M}$ or $\mathrm{F}$

Age___ (in years)

Level of College Student: $\quad$ Freshmen, Sophomore, Junior, Senior, Graduate, PhD Student

\begin{tabular}{lllll}
1 & 2 & 3 & 4 & 5 \\
\hline
\end{tabular}

\section{Strongly Disagree Disagree Neutral Agree $\quad$ Strongly Agree}

12345 1. The mission statement of UIW is clear to me.

$12345 \quad 2$. I feel today's service learning activity showed my commitment to helping others in the community.

12345 3. I expect today's project enhanced my personal development as a college student.

12345 4. I believe service learning projects give the student the ability to understand the needs of the community.

12345 5. I have made a connection between what has been learned in the class room and today's community service.

Comments: 


\section{Copyright Disclaimer}

Copyright reserved by the author(s).

This article is an open-access article distributed under the terms and conditions of the Creative Commons Attribution license (http://creativecommons.org/licenses/by/3.0/). 